\title{
Contemporary Grammars of Meaning Creation: Scientific Creationism and New Atheism
}

\author{
Ruben Sanchez-Sabate (D)
}

check for updates

Citation: Sanchez-Sabate, Ruben. 2021. Contemporary Grammars of Meaning Creation: Scientific Creationism and New Atheism. Religions 12: 166. https://doi.org/ $10.3390 /$ rel12030166

Received: 18 December 2020

Accepted: 18 February 2021

Published: 5 March 2021

Publisher's Note: MDPI stays neutral with regard to jurisdictional claims in published maps and institutional affiliations.

Copyright: (c) 2021 by the author Licensee MDPI, Basel, Switzerland. This article is an open access article distributed under the terms and conditions of the Creative Commons Attribution (CC BY) license (https:// creativecommons.org/licenses/by/ $4.0 /)$
Centro Internacional de Estudios Frontera, Núcleo Científico y Tecnológico en Ciencias Sociales y Humanidades, Universidad de La Frontera, Temuco 4811230, Chile; ruben.sanchez@ufrontera.cl

\begin{abstract}
This article approaches the grammars of meaning creation by Scientific Creationism and New Atheism from an anthropological-communicological perspective. By grammars of meaning creation, we understand the different languages that the human being uses to communicate the meaning of their existence to themself and others. Nowadays, Scientific Creationism is disseminated around the world and has transcended evangelical Christianity by permeating non-Christian religions. On the other hand, New Atheism, headed by Richard Dawkins, has also reached non-Western cultures such as Muslim cultures. Starting from Apelian transcendental semiotics, the hermeneutics of Durand's symbol, and Lluís Duch's anthropological study on mythos and logos, we reflect on the horizons of understanding of both movements. Our study shows that, contrary to what one might think given the antagonistic metaphysical positions the two movements seem to profess, Scientific Creationists and New Atheists share the same grammar of meaning creation: positivism. What one could interpret as a new epistemological controversy between science and religion can be better understood as a fight based on positivist science to establish the true origin myth. Thus, creationists and atheists implicitly recognize positivism as the contemporary theological discourse, i.e., the self-evident grammar of meaning creation that allows the Truth to be expressed.
\end{abstract}

Keywords: Scientific Creationism; New Atheism; grammars of meaning creation; religion; science

\section{Introduction}

Since Darwin published The Origin of the Species in the 19th century, American religious fundamentalisms have fought to fit the story of Genesis with the scientific theory of origins, arriving at the development of "Scientific Creationism" or the "science of creation" in the 1970s. Known as Creationists, these religious groups spread the current "intelligent design": a set of scientific arguments from the fields of biochemistry and mathematics that say they can demonstrate an "irreducible complexity" in cells that in no way could have occurred by chance and, therefore, requires a designer. This Creationist movement is no longer just an American phenomenon of Seventh-day Adventists or Baptists. Since the end of the 20th century, Creationism has expanded around the world and has been developed in Catholicism, Eastern Orthodox, Islam, Judaism, and even Hinduism. In Latin America, it has been present since the end of the 1990s, particularly in Mexico, Bolivia, and especially in Brazil.

At the same time, what phenomenologically we could call "atheistic religious movements" have arisen, dedicated to resisting the Creationists' arguments and promoting a meaning of life based solely on scientific evidence. Dr. Richard Dawkins is the clearest example and his book The God Delusion is the most famous work of this militant atheism. Next, we will briefly describe Scientific Creationism and New Atheism to then address their grammars of meaning creation from transcendental semiotics, hermeneutics, and communication anthropology. We will endeavor to show that, if at first glance, one can speak of a new controversy between science and religion, in fact both movements live on the same horizon of understanding: a positivist outlook so prevalent today. 


\subsection{Scientific Creationism}

There is no more exhaustive historical study on Creationism than the study by Ronald L. Numbers (Drees 2013), son of an American Seventh-day Adventist pastor and currently Professor Emeritus at the University of Wisconsin. Titled The Creationists (Numbers 2006), this work reconstructs the formation and evolution of Creationism in the US throughout the 20th century and includes a chapter dedicated to the expansion of Creationism in the rest of the world. Numbers' work shows that, although the Seventh-day Adventists and Baptists are the Protestant or evangelical denominations that have basically contributed to its development, Creationism has become a heterogenous movement that has been changing throughout the past century, and to which the rest of the American society-and, recently, the world-has been paying more attention as its number of followers has grown (Numbers 2006, p. 368). Arkansas legislation defined Creationism, thus, in 1981:

"Creation-science includes the scientific evidences and related inferences that indicate (1) sudden creation of the universe, energy, and life from nothing, (2) the insufficiency of mutation and natural selection in bringing about development of all living kinds from a single organism, (3) changes only with fixed limits of originally created kinds of plants and animals, (4) separate ancestry for man and apes, (5) explanation of the Earth's geology by catastrophism, including the occurrence of worldwide flood, and (6) a relatively recent inception of the Earth and living kinds." (Numbers 2006, p. 7)

From the history that Numbers recounts, we are interested in the understandings that Creationism has had about the Bible generally and Genesis, in particular, on the one hand, and about science and its method on the other hand. In the first stage that covers the first 75 years of the last century, reference was made to the "doctrine of evolution" and the "doctrine of special creation" (Numbers 2006, p. 268). The creationists based this way of understanding the theory of evolution on the Baconian idea of science, i.e., as the empirical exercise of collecting data (Numbers 2006, p. 274). Both were considered beliefs about unobservable events, and, therefore, in no case could they be understood as scientific: at most, origin philosophies (Numbers 2006, p. 268).

It was not until the mid-1970s that the Creationists began to reconsider their understanding of these "doctrines." Rather than questioning the science of evolutionism, they sought to make the doctrine of creation a scientific theory comparable to Darwinism. From that point, Christian scientists dedicated to the cause began to speak of "Creation Science" and "Scientific Creationism." The reasons for this change in tactics were legal and cultural. In 1963, when the US Supreme Court outlawed prayer and Bible reading in elementary and secondary public schools, it also prohibited states from establishing a "secular religion" (Numbers 2006, p. 243) in these schools, i.e., actively opposing all religious perspectives. This was taken as an opportunity by the most conservative Christians to ask education and legal authorities, first, to declare evolutionism a "theory" and, second, to teach Creationism in biology classes as an alternative to Darwinian theory (Numbers 2006, p. 270). The cultural reasons have to do with the loss of Biblical authority in an increasingly secularized society. It was necessary to develop a scientific justification for divine creation that would enable evangelicals until today to enculturate their offspring in the Christian cosmology legitimized by the Bible (Numbers 2006, p. 270). Building on the opinion of Karl Popper, for whom Darwinism was a "metaphysical research program" that can serve the purposes of science well as "a possible framework for provable scientific theories" (Numbers 2006, p. 274), and taking the ideas of Thomas Kuhn on scientific development as theoretical models and frameworks that compete with each other instead of a simple and unrealistic accumulation of knowledge, and on extra-scientific factors such as the biographical and idiosyncratic that influence scientists when they exhibit a preference for one or the other scientific paradigm (Numbers 2006, p. 275), the creationist scientists proposed "to show that the facts of science can be explained in terms of the scientific model of creation" (Numbers 2006, p. 276). 
Continuing down this road, in the 1990s, the theory of Intelligent Design (ID) began to spread, thereby, initiating the third stage in the development Creationism. The first book that explicitly promoted ID was published in 1989. Titled Of Pandas and People: The Central Question of Biological Origins, it sought to supplement high school biology textbooks (Numbers 2006, p. 375). One of its authors, a mathematician and information theoretician called William A. Dembski, published The Design Inference: Eliminating Chance through Small Probabilities in 1998, a book centered on demonstrating the low probabilities of the spontaneous or accidental appearance of organisms, and establishing a method able to detect intelligence in their structures (Numbers 2006, p. 384). Two years earlier, biochemist Michael J. Behe published Darwin's Black Box. The Biochemical Challenge to Evolution, in which he expressed his doubts about the ability of natural evolutionism to explain molecular life and in which he presented one of the principal concepts of ID: "irreducible complexity," referring to those biological structures that can only fulfill their function when all parts are present and that, therefore, they cannot have been the fruit of the evolution of less complex structures. In addition, this is where ID must be drawn upon. Thus, considering only the scientific evidence and not "sacred books or sectarian beliefs" (Numbers 2006, p. 383), Behe argued that the complexity of subcellular organic structures can only be explained as the result of an intelligent design (Numbers 2006, p. 383). In 1996, Dembski, Behe, and other scientists founded the Center for the Renewal of Science and Culture, with the clear aspiration to end "scientific materialism" and promote "nothing less than a scientific and cultural revolution" (Numbers 2006, p. 382) that made it possible to consider supernatural or theist causes in the explanation of the origin of life. However, and despite their efforts, ID continues to be rejected by the majority of the scientific community. Unable to publish articles in scientific journals, the promoters of ID are dedicated to encouraging debate on the philosophy of science among the general public (Peterson 2002).

\subsection{The New Atheism}

The so-called New Atheism (NA) is a more recent cultural phenomenon that is still developing and is associated with the publication-with great success among the lay public - of books against God and religion signed by scientists and philosophers with the most famous being The God Delusion (2006), written by Richard Dawkins, nicknamed "Darwin's Rottweiler" (Pigliucci 2013). The Merriam-Webster Dictionary defines an atheist as a person who "does not believe in the existence of a god or any gods." This definition is that of positive atheism, whereas the negative version has to do with the etymology of atheos, which would come to mean "without God" or without belief in any god (Thomas 2010). The genealogy of atheism can be traced to the pre-Socratic atomists (Pigliucci 2013), and two currents can be distinguished: one interested in the impartial search for the truth and another of clear invective drive against gods and religions (Amarasingam 2010, p. 2).

This second line is the one that the representatives-or should we call them soldiers?of NA are developing. Since 2004 when philosopher Sam Harris, who soon after would begin a doctorate in neuroscience, published The End of Faith, there has been a series of books advocating for NA that have all been bestsellers. In Harris's book, 33 weeks on the New York Times bestseller list, it is written that religious belief inspires the worst atrocities and threatens the survival of civilization (Thomas 2010). A few years later, zoologist and biologist Dawkins published his most famous aforementioned book, which sold, in a little over a year, a million and a half copies, and has been translated into 31 languages (Thomas 2010). In it, Dawkins states that "the God hypothesis" can be considered a scientific hypothesis and, therefore, given the lack of evidence, it must be discounted. For the New Atheist community, Dawkins' book is the substantiation that science has definitively undermined the idea of God (Pigliucci 2013). Already in 2007, particle physicist Victor J. Stenger launched God: The Failed Hypothesis: How Science Shows That God Does Not Exist on the market, which is another bestseller that argues against the existence of God, and states that it is possible to live morally in society without gods. Moreover, Stenger treats God as a scientific hypothesis that must be rejected (Pigliucci 2013). 
These three works we have presented are possibly the most representative of NA, but there are many others such as Breaking the Spell: Religion as a Natural Phenomenon (2006) by philosopher Daniel Dennett, another by Harris titled Letter to a Christian Nation (2006), God Is Not Great: How Religion Poisons Everything (2007) by Christopher Hitchens, Irreligion: A Mathematician Explains Why the Arguments for God Just Don't Add Up (2008) written by mathematician John Allen Paulos, How the Bible Fails to Answer Our Most Important Question-Why We Suffer (2008) signed by a New Testament professor who has lost his faith, and, finally, another book by Harris titled The Moral Landscape: How Science Can Determine Human Values (2010) (Thomas 2010; Pigliucci 2013).

Until the 21st century, atheism always argued from the philosophical plane. The writings of A. J. Ayer, John Dewey, and Bertrand Russell are good examples of this. NA represents a novelty in the following ways: (1) its enormous popularity (Pigliucci 2013), which some have interpreted as a social revival similar to what occurs among English-speaking evangelicals (Amarasingam 2010, p. 2), and (2) its scientific nature, understanding scientism as "a totalizing attitude that regards science as the ultimate standard and arbiter of all interesting questions; or alternatively that seeks to expand the very definition and scope of science to encompass all aspects of human knowledge and understanding" (Pigliucci 2013). Although atheism has made us accustomed to opposing gods and religion for moral and political reasons, NA is supported by epistemological reasons (Amarasingam 2010, p. 5). Thus, they discount the notions of soul and faith because both are based on unrealistic ideas about how the human mind actually works (Amarasingam 2010, p. 6). They make God a hypothesis that must be subjected to the scientific method (Amarasingam 2010, p. 8). Ultimately, what the New Atheists pursue is the substitution of philosophy for science (Pigliucci 2013).

\section{Grammars of Meaning Creation of Scientific Creationism and New Atheism}

The brief description just provided about Creationists and New Atheists underscores the insurmountable differences between them in terms of the meaning and origin of life. The explicit contents of their respective discourses are antagonistic. It is easy to consider both movements as contemporary—for many, radicalized-expressions of the science-religion/Church-State struggle that has existed in the West since the 16th century. In addition to a fight for power, this struggle has occurred in particular in the fields of epistemology and methodology.

When we speak of human knowing, we are referring, from the anthropological point of view, to the objectivization of perception through symbolic capacity, whose expression par excellence is the word. Following certain semiotic rules (semantic, syntactic, and pragmatic), the human being can create multiple meanings from a common biology and the same environment. Building on George Steiner, we could speak of "grammars of creation", i.e., the act of knowing as "the articulate organization of perception, reflection, and experience" (Steiner 2011). Indeed, the disputes that have occurred between science and religion are founded on the different grammars of meaning creation that they practice. The way in which each articulates the human experience is different. It is not strange, then, that scientists like Stephen Gould and many others have sought a way to make religion and science compatible and, thus, avoid one ending up canceling out the other (Murray and Rea 2008, p. 198).

Next, we will address the grammars of meaning creation of Creationists and New Atheist from philosophical semiotics, hermeneutics, and Lluís Duch's logomythics ${ }^{1}$. Thus, we will show that the matter at hand breaks with the traditional difference between religious and scientific or atheist grammars. Creationists and New Atheists take positivist science as the only source of authority to resolve metaphysical questions, transforming the

1 This is our translation of "logomítica", a term coined in Spanish by the Catalan anthropologist and theologian Lluís Duch. By "logomitica", Duch defines an anthropological-philosophical premise about human communication. This term is further explained in this paper. See Section 2.2. 
Bible into scientific evidence on the one hand, and, on the other hand, reducing the content of thoughts to mere biochemical reactions.

\subsection{Symbolization and Meaning in Scientific Creationism and New Atheism}

In the first half of the 20th century, philosopher Ernst Cassirer asserted that the cornerstone of all human creation, including science and religion, is the symbolic capacity that unites contents or meaning of a spiritual nature with sensory contents, whether these are visual or acoustic, as in the case of the word (Vog1 1999, 4:42). Thus, human knowledge, always mediated by the symbol, is the origin of the human world or reality, and not something produced within the world or environment. Reflecting on the human being's symbolic capacity, Cassirer distinguished between sign and symbol. The former is univocal, i.e., the relation between sign and object-or between signifier and signified in Saussurean terms-fixed, stable, permanent. However, the symbol is ambiguous or plurivocal, implying that the same signifier, such as the Christian cross, can have multiple meanings. Karl Otto Apel, on the other hand, building on the work of Cassirer and Charles S. Peirce, proposed a transcendental semiotics that presents the elements that make semiosis possible, and, therefore, are essential to all types of human knowledge. These elements are the interpreter or subject, the sign or intersubjective linguistic system, and the designated or denoted object (Apel and Lapiedra 2002; Apel et al. 1994; De Zan 1994). Metaphysical Truth, then, is always explained (erklären) as intersubjective semiosis, no matter how much the understanding (verstehen) of it varies according to sociocultural circumstances.

As Numbers explains, many Creationists believe in the "verbal inerrancy" of the Bible (Numbers 2006, p. 371). To assume verbal inerrancy implies something more than attributing authority to the sacred text. It implies endowing the Bible with a specific ontology that, consequently, will demand a certain epistemology and methodology for its interpretation. When we speak of ontology, we are speaking of semiosis, according to Apel. The triple semiotic relation between interpreter (creationists), linguistic sign "Bible," and object (Bible) creates an object different to what, for example, would be an independent text for Paul Ricoeur, i.e., a text requiring interpretation and multiple interpretations. Creationist semiosis, however, makes the Bible a natural rather than a cultural object, in which God is revealed in the same way as He was in nature for scientists like Isaac Newton. Biblical words, then, cease to be words of the natural language (symbols) and become terms (signs), as if it were a scientific text. In the field of epistemology, it could easily be argued that hermeneutics opens the way to a literalist reading of the Bible. As an example of what we have just said, it is worth noting the rejection by some creationists of a book published by a professor of law at UC Berkeley titled Darwin on Trial (1991) due to "its lack of reliance on the literal statements of the Scripture" (Numbers 2006, p. 377) (our italics). Incidentally, this literalism is a trait also shared with the New Atheists. In a public conversation Dawkins held with other prominent New Atheists back in 2007, he said "The academic theologians, bishops, and vicars will attack us for taking scriptures-or for accusing people of taking scriptures-literally: [ ... ]", to which New Atheist Sam Harris added:

"Another point there is that they never admit how they have come to stop taking it literally. You have all these people criticizing us for our crass literalism-we're as fundamentalist as the fundamentalists-and yet these moderates don't admit how they have come to be moderate. What does moderation consist of? It consists of having lost faith in all of these propositions, or half of them, because of the hammer blows of science and secular politics." (Hitchens et al. 2019).

It is true that, from the point of view of Ricoeur's triple mimesis, i.e., the prefiguration, configuration, and refiguration of the text (Ricoeur 2004, p. 114), the Creation story in Genesis instructs the interpreter to make a literal reading of it. In comparison with the Egyptian culture from which the Hebrew people emerge according to the Biblical story, Genesis is a remythization of the cosmology in which nature stops meaning different deities, like the sun meaning the creator god Aten or the gazelle the goddess of water, to become mere creation of an invisible god that creates by his word (Flori 1983). From the 
semiotic point of view, nature stops being an ambiguous symbol and becomes a univocal sign. From Durand's hermeneutics (Durand 2007), we could say that nature loses its evocative, establishing, creative power that it had as a symbol of different deities, being reduced to a mere univocal sign at the disposal of the human being. Not in vain does God say to the human couple that they should subjugate and have dominion over the Earth (Genesis 1:28). The disenchantment of the world that produces science finds in Genesis a fundamental precursor. Even so, the disenchantment of the Egyptian cosmology that produces the Hebrew story is not total nor, therefore, can it be totalitarian. The creator God, of which we only know that He speaks and that He judges his work as good, has not been converted to a sign. It is a symbol, in the Cassirerian sense, because it is not defined, is not associated with any meaning, and only its creative action is spoken of. God is a symbol of the power from which the signs originate that create the Hebrew cosmology. What makes Creationism scientific is going all the way and making God a sign as well. One of the precursors of ID said that this theory makes it possible to state that "God is objectively real as creator, that the reality of God is tangibly recorded in evidence accessible to science, particularly in biology" (Clayton 2012, p. 18). The creator God of Genesis 1 who is barely named becomes in Creationism an object, the cause of an effect that is observable from biology. The difference with Deism is that the Creationist god continues to hold the power to intervene in history. But it is a power in the service of man. Making god a sign, divinity becomes an object at the disposal of the human being. Man, ultimately, defines the object, which is, in this case, divinity. Now it is the human being who "creates" god, as it is no longer god, as a symbol, who creates the human being. This type of semiosis applied to the Hebrew text, then, would seem to also reduce the possible moral influence that the story could have on the believer, since Genesis ceases to be a text to communicate- to make sense of life in common - and becomes "data," according to Creationist philosopher Fernando Canale for whom the "doctrine of creation begins with a detailed exegesis of all biblical data related to the creation of the world, but then proceeds to demonstrate that creation is a divine action that includes a divine pattern and purpose." (our translation and our italics) (Canale 2009).

We now look briefly at the case of the New Atheists. In The God Delusion, Dawkins presented a series of arguments against religion and God based on "the existence of God being a hypothesis like any other" (Watson 2010). Like scientific Creationism, God is a real and tangible object whose existence is susceptible to being verified by the scientific method. There is no place for transcendence: divine reality is reduced to immanence. In terms of beliefs, Dawkins differentiates the scientific from the religious as being based on evidence and able to produce results, not so "myths and faiths" (Clayton 2012, p. 25). The virtues of science would be, among others, "quantifiability," "intersubjectivity," "universality," and "independence of cultural milieu," which are qualities absent in religion (Clayton 2012, p. 28).

It is evident that New Atheism works with the grammar of meaning creation of science. Science demands instrumental signs, i.e., univocal symbols that allow the subject to carry out its vocation of dominion. From Apelian transcendental semiotics, it is possible to see that, for Dawkins and others like him, the only valid use of the sign, or, said another way, the only true way that the sign has to relate the subject to the object is univocity. The only word to consider for the act of knowing is the univocal word-sign, the instrumental word inherent to science, thus, rejecting expressions such as poetry as a valid source of true meaning and knowledge. All of human reality is limited to the use of the sign inherent to the vocation of dominion. In what is sold as "the conversation that sparked an Atheist revolution," the following exchange between two of the most famous representatives of New Atheism illustrates this point:

“C. HITCHENS: It would be very improbable that people wrote [devotional] poetry like that [of John Donne or George Herbert] to please anyone. 
R. DAWKINS: But in any case, what conclusion would you draw? If Donne's devotional poetry is wonderful, so what? That doesn't show that it represents truth in any sense.

C. HITCHENS: Not in the least. [ ... ]" (Hitchens et al. 2019).

\subsection{Mythos and Logos in the Discourses of Creationists and New Atheists}

Lluís Duch's logomythics (Duch 1998, p. 456 and ff.) is an anthropological premise of human communication (Duch and Chillón 2012), which posits that myth and reason are two ways of speaking and, therefore, knowing. They cannot and must not be separated. The human requires both to provide an outlet to the expressive need of his spirit. Structurally, the anthropos is mythical and logical at the same time. Duch states that, in all mythic discourse there is logic, and vice versa. Broadly speaking, the mythos is image, synthesis, experience, affect. Its form is narrative and imaginal, offering powerful, authoritarian and self-evident words with which to relate past and future to the present. By contrast, the $\log o s$ is concept, reason, analysis, experiment. Its form is argumentation. They are words of calculation, reflection and discussion. The relation between mythos and logos is not symmetrical. As Duch gathers from the thinking of Raimon Panikkar, the myth creates the envelope within which the logos can fully develop. In every argument, in every logos, a mythos is the underpinning (Duch 1998, p. 221).

In our opinion, scientific Creationism and New Atheism are two logos, two argumentative discourses based on the same mythos, as antagonistic as their declarations may be. This is to say, the defenses of their respective viewpoints for or against the existence of God rest on the same suppositions, the same beliefs. If both movements can discuss the origin of life and the nature of the cosmos, it is because, as we will see next, both groups perceive the world from the same horizon of understanding: the mythos of positivism.

The reader knows that positivism is a philosophy of science that enjoyed widespread acceptance in the 19th century (Delanty and Strydom 2003). There are at least three positivist movements (Ferrater Mora 1999): (a) classic positivism, which refers to the thought of Auguste Comte and Stuart Mill's philosophy, (b) 19th-century positivism based mainly on the works of David Hume with different branches like Ernst Mach's sensationalism or the idealistic positivism of the Neo-Kantian philosopher Hans Vaihinger, and (c) 20th-century neopositivism developed in the Berlin and Vienna circles. Since there are big and small differences between them-and even between their respective branches-it is hard to establish their common traits (Ferrater Mora 1999). For this paper, it should suffice to first, remind the reader of the general and most salient characteristics of positivist philosophy, and, second, describe what it is that we mean when we speak of "the mythos of positivism".

It is fair to say that positivism is a theory of knowledge (Ferrater Mora 1999). Based on naturalistic metaphysics, facts are understood in phenomenalist or physicalist terms. Investigating with the inductive method without prejudice or preconception, these facts allow the scientist to develop a theory (Delanty and Strydom 2003). Some general traits of positivism-keeping in mind that 20th-century neopositivism criticizes some aspects of 19th-century positivism - are the following: (1) As a theory of knowledge, positivism refuses to admit any reality other than facts and to investigate something other than the relationships between facts, (2) unified science: all the scientific disciplines can be reduced to the physical, (3) empiricism: an anti-metaphysics position that states that knowledge is only what is the fruit of experience, (4) separation between facts and values, descriptive and normative statements, and (5) instrumentalism: an orientation toward manipulating the world rather than understanding it. In other words, positivism emphasizes the how, and avoids responding to the what, the why, and the what for (Delanty and Strydom 2003; Ferrater Mora 1999). Finally, it is necessary to mention a fundamental trait of neopositivism because it is also fundamental to New Atheism, i.e., the empiricist principle of verificationism. In a nutshell, this verifiability theory of meaning posits that "if a sentence has no possible method of verification [by means of observation, meaning sensory experience], it 
has no meaning" (Godfrey-Smith 2009). This means that verifiable experience is the only source of meaning and knowledge (poetry, for instance, would fail the verifiability test and, thus, would be meaningless). Since philosophy, ethics, and theology are supposed to say factual things about the world, but what they say cannot be empirically observed, their affirmations can be dismissed as false (Godfrey-Smith 2009).

By the mythos of positivism, here, we mean a horizon of understanding built upon a (neo)positivist conception of the Truth. By "Truth," here, we mean the always provisional—and usually taken for granted-answer to the anthropological need of basic meaning and orientation. The fact that people without meaning cannot function implies that such meaning needs a foundation, that is, a more or less conscious belief of what is or can be true, a belief of how it is possible to know what is true. Such belief generates the grammar of meaning creation that allows every human being to meaningfully organize his experience and, thus, inhabit this world. Therefore, by the mythos of positivism, we do not mean a fixed set of philosophical tenets that are necessarily rationally and consciously held but a milieu, a soil, (a culture? (Ryan 2015)) composed of more or less unconscious convictions and affects, stories, and images that make a positivist conception of reality (ontology), a (neo)positivist idea of how to know that reality (epistemology), and the acceptance of science as the only method to practically reach the Truth (methodology), the building blocks of truthful meaning (meaning full of truth).

New Atheism, as expressed by Dawkins and others (Hitchens et al. 2019), works on a mythos of positivist science. In the first chapter of a recently published book (Hitchens et al. 2019) aimed at a popular audience, Dawkins affirms:

"It's fascinating to see how the theological mind works: in particular, the lack of interest in-indeed, the contempt for-factual evidence. [ ... ] It [is not] that theologians deliberately tell untruths. It's as though they just don't care about truth; aren't interested in truth; don't know what truth even means;" (Hitchens et al. 2019) (our italics).

Dawkins considers any question that cannot be solved within the Darwinian paradigm as nonsense (Clayton 2012, p. 29). From its rationality, everything, even God, becomes a scientific hypothesis susceptible to being false (Watson 2010). Therefore, only what is supported by evidence, what is provable, quantifiable, intersubjective, universal, etc. is rational. As Dawkins understands, if "why" cannot be answered by science, it cannot be answered in any way. Ultimately, Dawkins imposes biological models on the sociocultural world (Watson 2010).

For the Creationists, it is worthy to note what one of the founders of the Creation Research Society reasoned while studying geology at UC Berkeley: namely, if the geological eras are true, it would be "foolish, indeed, to continue belief in the Bible" (Numbers 2006, p. 240). This form of reasoning explains why scientific Creationism has made so much effort to demonstrate Genesis 1 scientifically. On another occasion, the members of this association discussed what to believe from the creation story. The matter was settled by stating that the Bible is the written Word of God and that its assertions are true from the historical and scientific point of view, including Genesis (Numbers 2006, p. 256). Much later, the Adventists at the Geoscience Research Institute asserted that it was possible to believe in God without thinking of the great flood that, by then, had been discredited by the geological eras (Numbers 2006, p. 322). Currently, defenders of ID do not believe in the Hebrew story of creation and are satisfied with demonstrating the existence of a "designer" scientifically. What can be seen in all these cases is the assumption that Genesis and the scientific literature share the same ontological and epistemological presuppositions and that, therefore, Genesis can be discredited by scientific knowledge. The efforts made by the Creationists to marry the creation (hist)story with contemporary scientific knowledge leaves aside the sociocultural objectives that it could have because it assumes that the truth of the story is based on the veracity and verifiability of the narrated facts from a naturalistic 
(scientific) point of view ${ }^{2}$. Thus, it ignores that the sociocultural revolution that this story spawned is what made the scientific revolution possible later. It ignores that the story of Genesis gave light to a new world view of which the spirit continues to remain in effect in Western civilization.

Scientific Creationism and New Atheism create their logical discourses outside Theism, Deism, and Darwinism, precisely because both groups strive to defend these paradigms. The logic of their respective discourses is based on "the contemporary theological discourse" of positivism. By theological discourse, Duch understands "that discourse that is not put at issue, that discourse that is accepted because one is convinced of it consciously and unconsciously" (Duch 2005). This is to say, the theological discourse is the mythos that envelops the logos of society. It is not questioned, it is understood as self-evident, and it can only be known in its totality from another mythos. For Duch, secularization is the change of ownership of the theological discourse, passing from the clergy to the State, from religion to science. Nowadays, it is reasonable to think that theological discourse is in the hands of a type of science, the positivist, which makes economics a science of sociocultural dominion, and the indicators and hard data the best and greatest evidence of its discourse (Morley et al. 2014). This positivist spirit, with its nuances, obviously, since we are simplifying here, is present not only in the so-called hard sciences, but also in the social sciences, even today, despite having been heavily criticized during the 20th century from other philosophies of science such as the interpretative tradition, pragmatism, and transcendental semiotics. In our opinion, the main difference between positivism and these philosophies of science is that positivism hides the subject whereas the others strive to show it. Positivism reifies science by hiding the subject that pronounces the word that creates the world, when, in fact, as authors like Cassirer and Peirce have shown, it is the subject using the symbol, the word in this case, that creates human reality. When hiding the subject that pronounces the word, positivism restricts, limits, the possibility of developing theological discourse to those who are in a position of power, which facilitates dominion over the other enormously.

It is this power that the scientific Creationists and New Atheists claim. Both understand, consciously or unconsciously, that the mythos, theological discourse, is based on a concept of positivist Truth. The grammar of meaning creation of a discourse that empowers a few to dominate many is positivist reason. This is quite evident in the case of the New Atheists, but it should also be evident in the case of the Creationists when they are forced to resort to the theological discourse of Science in an attempt to preserve the authority and power of Biblical theological discourse. When the latter occurs, it is already too late to preserve the Biblical mythos—or Theological, in reference to the Auguste Comte's "three stages" - since another source of authority has already been accepted.

It is only possible to leave a mythos, a horizon of understanding, by entering a new mythos, as in this case, positivist reason. The point at which Creationists and New Atheists discuss which mythos is true, the theist or the Darwinist, is because both movements observe from a horizon of understanding different from what we just mentioned. It is clear that science has transformed the view that humanity has on the ontology and epistemology of what is real, true, of the cosmos that embraces us (Clayton 2012, p. 1). From positivist reason, Creationists and New Atheists evaluate the Hebrew and Darwinian accounts of the origin of reality, each defending theirs, trusting that the authority and self-evidence of positivist science will end up showing they are right. In this case, the description becomes true that Comte makes of the history of human knowledge: theology and metaphysics, theological discourses of long ago of believers in God and atheists, are surpassed by positivism. Here is the "story," the self-evident mythos that supports the condition of

2 Seventh-day Adventist Creationist philosopher Fernando Canale authored an introductory book to the scientific and theological methods in which he argued that "[t]he entire system of biblical theology works within the same historical understanding of reality and follows the same causal dynamics of interaction between the Creator and the creature. If creation week does not reveal how things really happened, then there is not much reason to believe what it says about salvation or eschatology. If the week of creation did not happen, then there was neither a perfectly created first couple nor an origin of evil due to the disobedience to the historical order created by God." (our translation) (Canale 2009) It seems that, for Canale, the theological value of Genesis is dependent on the factuality of the Genesis events. 
theological discourse that positivist reason holds in the globalizing West today, at whose altar Creationists and New Atheists prostrate themselves in equal measure. This is about the idolatry to positivist scientific knowledge because one forgets that this knowledge is the fruit of human action (Deut. 4:28). It is reasonable to think, from an anthropological and sociological point of view, that both movements are theodicies, praxis of domination of the contingency according to Duch, in such a liquid world (Bauman) for the Northwestern Hemisphere and so solid for the victims of capitalist globalization in the rest of the world (Watson 2010). The two theodicies are diametrically opposed, yet supported by the same cornerstone: a positivist outlook.

\subsection{Creationists and New Atheists in Search of Logomythicity}

The human being has a perennial need to recount his life to himself and the other. For this, he has mythical expressions and logics that, when combined in the right measure, facilitate a healthy journey through this world. According to Mircea Eliade, myths

"narrate not only the origin of the World, of animals, of plants, and of man, but also all the primordial events in consequence of which man became what he is today-mortal, sexed, organized in a society, obliged to work in order to live, and working in accordance with certain rules" (Eliade 1963, p. 11).

Both the creation story and Darwinian story of the evolution of species are histories, narrations, mythical expressions that give an account of the origins of life and the cosmos. They are protologies, origin myths essential to answering questions about identity like "who am I, where do I come from, and where am I going?". Science, or the scientific method, however, is a logical expression of the subject interested in explaining, understanding, arguing, and countering the reality imposed on the immanence of living. The cases of Scientific Creationism and New Atheism present opposing routes in the constant combination of mythos and logos that human existence requires. Creationists work from the supposed truth of the Biblical mythos toward a scientific logos that allows them to argue the authority and veracity of the Hebrew protology. What happens is that the logos adopted by the Creationists is not the logic that the mythos of creation offers. It is a logos that, as we have already seen, is based on the positivist mythos. It is not strange then that the Creationist movement has passed from defending the factuality of Genesis 1 to being satisfied with an ID that is said to demonstrate there is a designer (God), passing through intermediate phases in which it has been trying to fit the origin myth into scientific knowledge. In any case, the adoption of the scientific logos by the Creationists is a response to the anthropological need to give an account of human life logomythically.

For its part, New Atheism begins from the positivist logos, a way to explaining, understanding, arguing, and countering the immanent reality, toward the Darwinian mythos in search of that protology without which no human being can live. Note that the last work by Auguste Comte was published in 1851, and the first edition of Charles Darwin's Origin of the Species did not appear until 1859. Dawkins has thanked Darwin for having made it possible to be what we call a fulfilled atheist (Numbers 2006, p. 374). The positivist logos inherent in the positivist mythos of the stages of knowledge narrated by Comte finds in the story, in the Darwinian narration, a protology that respects the grammar of meaning creation of positivism, an origin myth that allows the original events to be understood as a consequence of which humanity has become what it is today. Thus, Dawkins will say that "the universe we observe has precisely the properties we should expect if there is, at bottom, no design, no purpose, no evil, and no good, nothing but blind, pitiless indifference" (Clayton 2012, p. 26). One can do nothing more than note the irony when contrasting this statement with the furious attacks that Dawkins launches against religion for considering it irrational. If there is no good or evil, how can it be said that science is good and religion is evil? In any case, Dawkins has made preaching that life has no meaning or purpose the meaning and purpose of his own life. New Atheism, then, finds in the Darwinian mythos the ingredient necessary to take positivism to the extreme 
and turn it into scientism. Thus, New Atheism becomes a "religious science" in the same way that scientific Creationism had already been transformed into a "scientific religion".

In other words, these two extreme cases show us that there is no possible human existence with only science (logos) or only religion (mythos). Human life requires both mediations. We are not beings who can be satisfied with immanence. We need transcendence; hence the need of all human beings to live in a protological and eschatological mythos. Creationists and New Atheists seek this transcendence in mythical and logical expressions because only the use of both allows the human being to lift a complete mundus, no matter how temporary it is.

\section{Conclusions}

The scientific Creationist movement and New Atheism share the same grammar of meaning creation based on the same positivist philosophy, which, incidentally, has predominated in Western globalizing institutions. Both movements recognize positivism as the contemporary theological discourse, as the mythos that envelops Western civilization, i.e., as self-evident discourse, that is taken for granted. Although their respective beliefs on the existence or not of God and on the origin of life and the cosmos are clearly antagonistic, Creationists and New Atheists are supported by the same authority that confers theological positivist speech to defend them. From a semiotic-transcendental and hermeneutic perspective, the positivist mythos leads them to reject the equivocal symbol inherent in daily language, literature, and the arts in general, when meaning is generated. The grammar of meaning creation that both movements use only accepts univocal signs that make it possible to exert the vocation of dominion inherent in science and that Creationists and New Atheists also wish for themselves. Finally, the logomythicity essential to humanity causes everyone to go out and seek what they are missing in their respective grammars of meaning creation. Thus, narration or the Biblical myth will find in science the logos to argue and analyze. This logical and positivist science will seek in Darwin's Origin of the Species, the narration, the "story," the myth that complements it.

Funding: This research was funded by ANID—FONDECYT de Postdoctorado, grant number 3200822. The APC was funded by ANID—FONDECYT de Postdoctorado $\mathrm{n}^{\circ} 3200822$.

Conflicts of Interest: The author declare no conflict of interest.

\section{References}

Amarasingam, Amarnath, ed. 2010. Religion and the New Atheism: A Critical Appraisal. Studies in Critical Social Sciences, Studies in Critical Research on Religion, v. 25. v. 1. Leiden and Boston: Brill.

Apel, Karl-Otto, Julio De Zan, Ricardo Maliandi, and Dorando J. Michelini. 1994. Semiótica Filosófica. Buenos Aires: Almagesto.

Apel, Karl-Otto, and Guillermo Lapiedra. 2002. Semiótica Trascendental y Filosofía Primera. Madrid: Editorial Síntesis.

Canale, Fernando Luis. 2009. Creación, Evolución y Teología: Una Introducción a Los Métodos Científico y Teológico. Madrid: Editorial Universidad Adventista del Plata.

Clayton, Philip. 2012. Religion and Science: The Basics. London and New York: Routledge.

De Zan, Julio. 1994. Filosofía y pragmática del lenguaje. In Semiótica Filosófica. Edited by Karl-Otto Apel. Buenos Aires: Almagesto.

Delanty, Gerard, and Piet Strydom, eds. 2003. Philosophies of Social Science: The Classic and Contemporary Readings. Maidenhead and Phildelphia: Open University.

Drees, Willem B. 2013. Intelligent Discourse on Intelligent Design. An Editorial. Zygon: Journal of Religion and Science, Online Version. Available online: https:/ / onlinelibrary.wiley.com/pb-assets/assets/14679744/Intelligent_Discourse_on_Intelligent_Design_ Revised-1509466042000.pdf (accessed on 4 March 2021).

Duch, Lluis. 2005. Antropología de La Interacción Entre Mitos y Logos a Propósito de La Fenomenología Del Acontecimiento Religioso En El Hombre Contemporáneo. Pensamiento. Papeles de Filosofía. Available online: https://revistapensamiento.uaemex.mx/ article/view/253 (accessed on 4 March 2021).

Duch, Lluís, and Albert Chillón. 2012. Un Ser de Mediaciones. Barcelona: Herder.

Duch, Luis. 1998. Mito, Interpretación y Cultura: Aproximación a la Logomítica. Barcelona: Herder.

Durand, Gilbert. 2007. La Imaginación Simbólica. Buenos Aires: Amorrortu.

Eliade, Mircea. 1963. Myth and Reality. New York: Harper \& Row.

Ferrater Mora, José. 1999. Diccionario de Filosofía. Buenos Aires: Editorial Sudamericana.

Flori, Jean. 1983. Los Orígenes una Desmitificación. Madrid: Safeliz. 
Godfrey-Smith, Peter. 2009. Theory and Reality: An Introduction to the Philosophy of Science. Chicago: University of Chicago Press.

Hitchens, Christopher, Richard Dawkins, Sam Harris, D. C. Dennett, and Stephen Fry. 2019. The Four Horsemen: The Conversation That Sparked an Atheist Revolution. First U.S. Edition. New York: Random House.

Morley, Louise, Simon Marginson, and Jill Blackmore. 2014. Education and Neoliberal Globalization. British Journal of Sociology of Education 35: 457-68. [CrossRef]

Murray, Michael J., and Michael C. Rea. 2008. An Introduction to the Philosophy of Religion. Cambridge Introductions to Philosophy. Cambridge and New York: Cambridge University Press.

Numbers, Ronald. 2006. The Creationists: From Scientific Creationism to Intelligent Design. Expanded ed., 1st Harvard University Press pbk. ed. Cambridge: Harvard University Press.

Peterson, Gregory R. 2002. The Intelligent-Design Movement: Science or Ideology? Zygon ${ }^{\circledR}$ 37: 7-23. [CrossRef]

Pigliucci, Massimo. 2013. New Atheism and the Scientistic Turn in the Atheism Movement. Midwest Studies in Philosophy 37: 142-53. [CrossRef]

Ricoeur, Paul. 2004. Tiempo y Narración I. Translated by Agustín Neira Calvo. México, D.F: Siglo Veintiuno Editores.

Ryan, Phil. 2015. Positivism: Paradigm or Culture? Policy Studies 36: 417-33. [CrossRef]

Steiner, George. 2011. Gramáticas de la Creación. Madrid: Siruela, ISBN 978-84-9841-789-0.

Thomas, Owen C. 2010. The Atheist Surge: Faith in Science, Secularism, and Atheism. Theology and Science 8: 195-210. [CrossRef]

Vogl, Thomas. 1999. Die Geburt Der Humanität: Zur Kulturbedeutung Der Religion Bei Ernst Cassirer. Hamburg: Meiner Verlag, vol. 4.

Watson, Simon. 2010. Review Essay: Richard Dawkins' The God Delusion and Atheist Fundamentalism. Anthropoetics 15. Available online: http:/ / anthropoetics.ucla.edu/ap1502/1502watson/ (accessed on 4 March 2021). 